\title{
Problems and limitations of university management
}

\author{
F.E. Rädel
}

Based on a farewell lecture delivered to the staff of the University of South Africa on Professor Radel's retirement as Viceprincipal of the University of South Africa, November 1978

Modern universities are under constant pressure to improve the management of their activities, because of the increasing complexity of their tasks and structure, and the demands of their fund-supplying environment. In certain ways universities are more difficult to manage than, say, the typical business enterprise: they inevitably have a dualistic decision-making and management structure (academic and administrative); and meaningful planning is handicapped by the vagueness and multiplicity of their objectives. Even within these limitations, however, much can be done to apply proven management principles to the management of universities, and the author draws on 30 years of experience in this field to give practical examples and guidelines.

S. Afr. J. Bus. Mgmt 1979, 10:87 - 92

Moderne universiteite is gereeld onder druk om die bestuur van hulle aktiwitelte te verbeter, sowel weens die toenemende kompleksiteit van hulle take en struktuur as die eise van die omgewing wat hulle van fondse voorsien. In sekere opsigte is universiteite moeiliker om te bestuur as byvoorbeeld die tipiese sake-onderneming: hulle het onvermydelik 'n dualistiese besluitneming- en bestuurstruktuur (akademies en administratief); en betekenisvolle beplanning word beperk deur die vaagheid en veelvoudigheid van hulle doelwitte. Selfs binne hierdie beperkings kan baie egter gedoen word om bewese bestuursbeginsels toe te pas in die bestuur van universiteite, en die skrywer put uit 30 jaar ervaring op hierdie gebied om praktiese voorbeelde en riglyne te gee.

S.-Afr. Tydskr. Bedryfst. 1979, 10:87-92
Modern universities have become capital-intensive multimillion Rand organizations using up an everincreasing share of public finance and of a nation's income. It is, therefore, not surprising that taxpayers and governments alike should cast a critical eye on how universities are run and how they ensure, by appropriate management methods, that the best possible use is made of such public funds. It is around this problem that two schools of thought have developed: on the one hand there is the view that universities are fundamentally different from business organizations, not only in regard to objectives but also in regard to functions and structure, and that, therefore, the application of business techniques is not only impossible but tends to lead to the destruction of the very essence of a university. On the other hand, it is argued that - in keeping with business organizations universities have to achieve certain objectives (whatever these objectives might be) with limited means, and that there is no reason why proven principles derived from business organizations should not be useful in the management of a university. In this paper an attempt is made to analyze the problems and limitations of university management objectively and sine ira et studio.

\section{Limitations of university management}

Universities have been in existence for many centuries and although initially they were rather loose associations or universitates magistrorum et scholarium they had to be administered in some or other way. Since they were predominantly either church, princely or publicly owned institutions, the administrative function was, as it were, located outside the university proper - as we find in the German university system to this day - while academic matters were governed by the magistri organized into faculties and senate. It is only comparatively recently that we speak of university management rather than administration, and it would seem that this indicates more than a change of terms, that is, a shift from a rather static to a more dynamic goal-directed approach in the running of a university. The reasons for this change of approach are manifold, of which but a few will be briefly mentioned: 
- The change from class societies to open societies in western countries resulted in a similar change from elite to mass universities, resulting in an exponential rise in student numbers.

- As a result of rising student numbers and increasing capital intensity, universities have become extremely expensive institutions. While - according to a study of European universities - about 1,5 to $2 \%$ of the national income is presently spent on universities in leading western countries, it is estimated that this percentage will increase to between 10 and $20 \%$ by the year 2000 . Although it is highly improbable that these estimates will ever materialize (other demands on the national income like health, social services, defence, protection of the environment, will probably receive higher priority), constraints will necessitate the optimum use of limited resources.

- A third, less obvious, but equally important reason for the demand for more purposeful goal-directed university management, is the general breakdown of traditional values in western societies, which cannot but adversely affect the university as an important part of society. Society seems to look for guidance from universities in the search for new values. Whether universities, as basically scientific institutions, can ever set such values is, of course, debatable. The famous German philosopher, Carl Jaspers, states that 'scientific knowledge cannot provide life with goals, values or direction'.'

All these demands made on universities of our time and the future, point to an increased sense of purpose, goaldirectedness, efficacy and efficiency. Essentially these are management tasks, since large organizations never adapt spontaneously to new demands; adjustments can only be brought about by conscious effort.

This raises the fundamental question as to whether and to what extent universities are at all manageable. Those who question their manageability argue, firstly, that the grave crisis experienced by most western universities at present is proof that a university cannot adapt to new demands of its own accord, and secondly, that a university is intrinsically and structurally different from a business firm from which the concepts and methods of management are derived. On the other hand, there are those who maintain that being a service establishment, a university does have the attributes of an 'establishment' and can therefore be managed accordingly.

According to accepted concepts of business economics, an establishment ('bedryf') is the totality and interaction of persons and means aimed at the creation of goods and services subject to the 'economic principle', that is, to achieve maximum results (output) with given means (input). Hence, wherever maximum results with given limited means are strived for, the economic principle applies and one can speak of an establishment ('bedryf'). The concept of an establishment, is therefore not confined to the legal and financial form of a capitalistic profitoriented firm but includes establishments in socialistic systems and such non-profit organizations as public corporations, hospitals and universities. In this sense an establishment is system-different or system-neutral. In fact, the whole dispute as to whether or not a university is an establishment in the above sense, arises from the confusion of the concepts 'establishment' and 'firm'.

The economic principle, furthermore, implies that clarity exists concerning the envisaged outputs or goals of an establishment, and, further, that the means or inputs should be organized, coordinated and directed in such a way that the pre-determined goals can be attained. This has finally to be ascertained by evaluating the actual results in terms of the pre-determined objectives. This is, in fact, a simple definition of the task and main functions of management, and it is obvious that essentially, these apply to the proper administration of a university as well.

Nevertheless, as an establishment, a university has specific attributes which create unique managerial problems and which limit its manageability. Only two of these will be examined in some detail: the dualistic decision-making and managerial structure and the vagueness of university objectives.

\section{The dualistic decision-making and management structure}

Fielden and Lockwood' write: 'The assumption is that universities are organizations which have corporate responsibilities and which possess powers to manage the activities of their members in order to carry out these responsibilities. They contain elements of the firm ... but also of the medieval guild'.

Faculties or departments are to some extent autonomous within a guild structure. At the same time they are integral components of an overall structure: the university. The same authors continue: 'This is a point to be stressed, since the extreme view that universities are protective guilds within which individual groups may operate as private entrepreneurs, is often strongly represented in universities.'

A university is a business enterprise, in that it strives to achieve its objectives in the best way possible by using specific means. It needs an authority structure whereby authority is vested in top management - Council and Rectorate (the executive body). The implementation of general policy is achieved by means of assignments in the form of operational policy formulation emanating from the top of the hierarchy and flowing down the line organization. Frequent consultation with lower levels on the formulation of strategic policy does not detract from the fact that managerial powers and final authority rest with top management.

Over and above this line hierarchy, one finds that universities practise what Arrièns calls 'akademiese selfbestuur in gemeenskapsverband' ${ }^{3}$ (academic autonomy in a community context). Academic bodies have virtually complete autonomy (explicitly laid down in one form or another in the various university acts) in respect of all academic matters such as syllabi, curricula, admission of students, examinations and recruitment of lecturing staff. To some extent the concept 'academic freedom' is embodied in this autonomy. All senior members of the academic staff participate in the decision-making process on an equal footing. Traditionally and by law, university management, that is Council, refrains from direct interference in academic matters. The executive (the Rectorate and the Rector in particular) acts as chairman of the Senate only in a capacity of primus inter pares, in- 
fluencing decision-making solely by the weight of his or their personal arguments. In respect of academic matters, therefore, we have a system of collegial management or direct democracy, or representative democracy, in that Senate delegates certain functions to executive bodies whose decisions are based on consensus wherever possible.

The result is a unique feature of university management - a dualistic structure, that is democratic management in respect of academic matters which operates, as it were, from the lower echelons upwards; and line management from the top downwards in all other regards. Consequently the scope for management in the strict sense of the word, that is directive management, is restricted in the academic field. Academic management displays predominantly decentralizing centrifugal features, whereas line management is characterized mainly by centripetal centralizing qualities.

Consequently the overall structure of university management is only partially comparable to that of a business enterprise. Arriëns summarizes this by observing that the whole problem of university management is characterized and dominated by the antithesis and stresses resulting from this dualism. In the daily routine of universities this is sometimes manifested in disputes concerning what should be regarded as academic matters and what should not, and in the phenomenon that academic impulses emanating from the university management tend to fizzle out and even disappear in the intricate mazes of the academic decision process. This inherent tension makes enormous demands on the understanding, patience and tact of all concerned. The fact that universities function the way they do, may be regarded as a feather in the cap of both line and academic management.

Vagueness and multiplicity of university objectives As has been repeatedly stressed, a clear definition of objectives in meaningful, concrete and specific terms is the cornerstone of efficient management in any organization. It is the basis for meaningful planning, for strategic and operational policy formulation, for the identification of the functions and activities to be performed, and for the design of an organization by which such functions are best to be performed. Clear objectives also give the university a distinctive profile towards the outside world and are a powerful motivating factor for the personnel. Above all, they provide an indispensable yardstick for the evaluation of an institution's performance.

In business enterprises the objectives can be related to monetary terms. So also can the performance or output in a given period be expressed in monetary terms, with the result that the latter can be related to inputs which are equally quantifiable in the same terms. Objective setting for universities is, of course, not as easy as it is in business practice and business economics and the management scientists will hopefully condone this oversimplification, which will, however, help to clarify the basic difference between business and university management.

What then is the situation in respect of university objectives? After a thorough study of Belgian universities, Albright concluded: 'In no university is there a clear statement or understanding of what its objectives are either for the institution as a whole or for the component departments'. 4

According to available literature and the author's own observations, this statement would seem to apply to universities by and large. The reasons for this state of affairs are manifold, of which a few can be highlighted as the most important.

The basic objectives of a university, namely education, research and, of more recent origin, direct service to the community, are by their very nature vague, inconcrete and manifold and therefore of little practical value for planning, policy formulation, and even less so as a yardstick for performance. How can we measure education? In terms of degrees? If so, is the quality of the degrees comparable at a given time or over time? Should we consider the time taken for a degree and if so, how? What is the relative weight of undergraduate and postgraduate degrees? Above all, can we be sure that a university, by awarding a degree, has really accomplished its fundamental educational task? One can see university education as - to use a term from economics - 'value added', which is the difference between the level of education at the beginning and the completion of university education. This 'added value' comprises of course much more than knowledge acquired; there is also the ability to think objectively, critically and logically, the acquisition of a more mature outlook on life, and above all, desire for the acquisition of further knowledge. Examination results upon which we confer degrees, are indeed a very poor measure of all these qualities.

The measurement of research outputs or research results in meaningful terms is even more elusive, as any researcher will agree, let alone the measurement of services to the community, like consulting services, conferences, continuing education programmes and the like.

Apart from the inherently inconcrete character of a university's main objectives, we find a great variety of sometimes even conflicting objectives, however vaguely they may be conceived. This is mainly due to the diffuse management structure of a university, as explained earlier on. One department may strive for increasing student numbers by offering new courses, another for a higher pass rate, one may give priority to undergraduate courses and discourage postgraduate study, another may lay heavy emphasis on research, one may stress the development of critical thinking, another one may concentrate on the transfer of factual knowledge. It is generally known that such differences in secondary objectives can and do exist even within academic departments. Whether and how far these different objectives can be justified by the concept of academic freedom, is a debatable question which is not relevant for the present line of argument.

Even if university objectives could be formulated in more concrete and uniform terms some critics maintain, as Palalo of the University of California puts it - 'that academic institutions generally tend to engage in goal evasion . . . because once the university determines its goals beyond a rhetoric sense, it is obliged to examine its capabilities in approaching these goals." - and, one might add, runs the risk of being judged by the community in terms of these goals. Others argue that a certain 
degree of antagonism among academics against concrete goal formulation, planning, evaluation and management generally stems from the medieval 'community of scholars' concept, which is not compatible with anyone managing and controlling anyone.

It can be summarized that university objectives are inconcrete, manifold and at times even conflicting. And even if they were concrete, it would certainly not be possible to relate them to a common quantitative denominator, as we find it to be in the case of business enterprises.

What has been said so far, makes it obvious that the dualistic decision-making and management structure and the vagueness and elusiveness of its objectives, set certain limitations to the proper unitary and goal-directed management of a university and the effective application of the various managerial methods and procedures. Nevertheless, nothing should prevent those concerned from trying to make the fullest possible use of the management concept within these somewhat narrow parameters.

\section{Some observations from experience}

What, then, are the possibilities within the parameters outlined above? The following observations are derived from more than 30 years of experience in one particular university - the University of South Africa (UNISA) and, although, hopefully, generally valid, are not necessarily applicable to each and every university - not even in South Africa.

\section{Formulation of objectives}

The impossibility of formulating university objectives quantitatively does not rule out attempts at defining them as concretely as possible, at least in qualitative terms. One example is the goal of consolidating the number of students and working towards a higher pass rate rather than permit unbridled growth in student numbers. The University of South Africa recently adopted a policy in this connection. Another example of qualitative formulation of goals is the stimulation of research in the area between purely personal and purely institutional studies by establishing research centres and units, or the objective of rendering more direct service to the community by establishing an Institute for Continued Education. While such objectives are marginally more concrete, they are still too vague for purposes of management. Hence an attempt must be made to transform such broad objectives into operational goals, such as a thorough revision of tutorial matter over a three-year period, or the formulation of research programmes as operational goals for the activities of research institutes and centres. Formulation of departmental annual programmes over and above routine obligations would encourage departments to consider new methods of study, envisaged research, the use of audiovisual aids and a general renovation of their activities. This too would be an instance of formulating operational goals.

\section{Planning}

There are two dimensions to university planning, national and internal. In South Africa the former was embodied in certain findings and recommendations of the van Wyk de Vries Commission which resulted in the institution of such bodies as the Advisory Council on
Universities, the Directorate of University Affairs at the Department of National Education, bodies concerned with building and cost norms, and such procedures as uniform budgetary systems and the SAPSE data system. National planning gave considerable impetus to such internal planning as was known at universities at the time. Essentially internal planning is simply the identification and scheduling of measures in pursuance of certain objectives. Hence the formulation of concrete goals is a prerequisite of meaningful planning.

To plan an improved pass rate - if we are to pursue our earlier example - requires reflection on such measures as better methods of study, selection and elimination of weak students, and improved instruction. Since, in the case of UNISA, greater contact with students could affect their performance significantly, the alternatives should be considered - decentralization by means of more regional or liaison offices, or more extensive use of modern communication media such as conference telephone systems from headquarters.

Longterm or strategic plans must be subdivided into short-term operational plans and reduced to staffing, physical and other needs, and ultimately reflected in the budget which is, in effect, simply an annual plan in monetary terms. The formulation and planning of academic objectives remain necessary preliminaries of physical and other planning, finally crystallizing in financial planning in monetary terms. Since in practice financial means are a datum, the planning process frequently has to be repeated until means and goals can be reconciled.

Contrary to this logical sequence, one finds at almost every university, both locally and elsewhere, that physical planning is given priority, followed by (or coinciding with) financial planning, with academic planning at the tail-end of the process.

Another common phenomenon is a lack of cooperation between physical, financial and academic planning, especially since these planning functions are usually in the hands of separate bodies or individuals. Cases have been known where academic and research bodies have decided on new programmes of study and research without considering the longterm financial and physical implications. At this stage, there is no clarity or consensus among universities as to the best way of effecting this coordination or of organizing the planning function, other than by placing it close to, or vesting it in, top management.

Effective planning depends largely on reliable cost data and sufficient pertinent information generally. As we have pointed out, planning usually requires an analysis and evaluation of alternatives, followed by a choice, for instance in the case of UNISA, between centralized or decentralized contact, leasing or owning premises, purchasing more library books, appointing more lecturers or providing better instruction - all of which could serve to improve the performance of students. All universities therefore have a great need for cost-benefit studies.

The other requirement for effective planning is sufficient relevant information. The advent of computers has meant a growing avalanche of data on many aspects of university activities, so that the problem is one of selecting what is relevant rather than of obtaining the data as such. Hence experienced university managers recommend 
the institution of an 'office of management information' charged with collecting, co-ordinating, processing and supplying data in a digestible form at the appropriate times not only to the planning section, but to the various levels and bodies of management. Judging from experience the author believes that such a centralized information unit would enhance the effectiveness of management at every level.

\section{Rationalization of decision-making processes}

A fundamental principle in this regard is that authority and responsibility are indivisible. Since the final responsibility for their respective spheres of authority rests with Council and Senate these bodies should actually take all decisions, which is manifestly impossible. The answer is to delegate decision-making powers. To ensure that such decisions accord with the spirit and general policy objectives of the final authority, delegation must be accompanied by the formulation of policy parameters. These have to be defined more closely and concretely, the further one proceeds to delegate down the line of authority. This is the only way to realize the second major principle of decision-making, namely that decisions should be made at the lowest appropriate level so as to leave the higher levels free to attend to more important matters.

Decision-making at universities can be rationalized yet further by streamlining the committee system which is rampant on campuses to a far greater extent than elsewhere. This can be done by spelling out the functions of committees which will often result in the merging of committees, by arranging their meetings in a rational sequence in the course of the year and especially by keeping them as small as possible. Universities are inclined to overlook the fact that the word 'committee' is a singular, 'a person to whom something or somebody is committed'. Compared with other universities with which I am familiar, UNISA has progressed quite a long way towards rationalizing its decision-making processes by meaningful and responsible delegation, by reducing the size of committees and by drawing up an integrated annual programme. However, there is still one aspect requiring thorough investigation, namely whether senates of the size of between 150 and 200 members can still serve their purposes, which is to thrash out academic matters. The larger the authoritative body, the greater the tendency to delegate differences of opinion to subordinate bodies instead of debating them and settling them at the top level. This slows down the overall decision-making process considerably.

\section{Organlzation and procedures}

Effective organization is likewise based on a clear grasp of the objectives of an institution or commercial enterprise. Only thus can the various functions be identified and an organizational structure be developed to perform these functions in the best possible way to achieve the aims.

Traditionally the organizational structure of the teaching function has been embodied in departments, faculties and Senate. With regard to group research which for various reasons is increasingly superseding individual research at universities - UNISA has created three organizational forms: research institutes, centres and units. Judging by the experience of the past three years, this has done much to promote research at the university.

At many universities administrative functions are in the hands of a diversity of people with no definite structures of rank or lines of authority. The first task facing university management therefore, is to coordinate them into meaningful units, or administrative and professional departments, each with its own clearly defined functions and a uniform structure of rank and remuneration. The principle, which appears so elementary but which is often overlooked in quite large sophisticated organizations, has been aptly phrased by Peter Drucker as 'one bad master is better than two good ones'. According to this precept, each official has to know his task and position in the organizational structure, and must know to which superior he is responsible. In the case of UNISA the various activities and procedures needed for effective cooperation by a large staff - both academic and administrative - are contained in the 'UNISA Manual'. .

\section{Control and evaluation}

The cornerstone of effective management is the evaluation and control of results in terms of the predetermined objectives. None the less this is the most neglected function of management even in business undertakings - as emerged again at a recent seminar on 'Management by Objectives' held at UNISA. At universities this deficiency is even more pronounced since the formulation of concrete goals is virtually impossible, with the result that no objective criteria exist. The University of Sussex has introduced 'critical indicators' by way of substitutes and uses them to evaluate the various activities. The particulars provided in the annual reports of lecturing departments at UNISA could be regarded as instances of this. As regards institutional research, the annual reports of the institutes and centres will, as from next year, be presented in a structured form and will give a clear picture of research findings. The reports of administrative and technical departments pose severe problems owing to the heterogeneity of their activities, but these difficulties should not be insurmountable. Reporting is invaluable since it compels the various departments to reflect critically on their activities, especially if the reports are preceded by detailed programmes containing predetermined goals that can be used as bench-marks for evaluation. To management such programmes and annual reports are significant, not only for purposes of evaluation but also because they cast light on problems that may require attention at top level.

\section{Conclusion}

In the author's opinion these few observations indicate sufficiently that the application of proven management principles and methods is not only possible within the limitations set by the particular character of a university, but is also indispensable for the efficient running of a modern, complex university. In fact, the unique structure and character of a university requires particular management experience and ability. It is here that we find a paradoxical situation in universities. For the training and development of management personnel in business organizations there is a great variety of specially designed 
university courses and degrees, and within-firm training programmes. No board of directors would dream of appointing a professor of history, medicine, theology or philosophy as general manager. This is, however, exactly what happens at universities. University principals are appointed mainly on the grounds of their scholarly achievements and put at the helm of a huge organization without any formal preparation or management training, which is the more remarkable since, as we have tried to indicate above, universities are in many ways much more complex organizations than business undertakings. Seen from this point of view university principals are doing a remarkably good job. Cynics may, of course, argue the other way round and say that the performance of university principals proves that management training programmes and business schools are luxuries and that we can easily do without them. Beethoven was certainly born a genius. It is doubtful, however, whether he could ever have enriched mankind with his immortal music had it not been for the formal lessons in counterpoint, harmony and the principles of composition which he received from his now-forgotten music teacher, Neefe. The increasing demands on the managerial ability, knowledge and background of university managers throughout the world might make it advisable - as it is indeed postulated in many quarters - to devise ways and means which will help to prepare them for their increasingly difficult task in a rapidly changing world.

\section{References}

1 JASPERS, K. The Idea of the University, Peter Owen, London, 1960 , p. 30.

2 FIELDEN, J. \& LOCKWOOD, G. Planning and Management in Universities; A Study of British Universities, Sussex University Press, 1973, p. 20.

3 ARRIENS, Th.E.H. Universitaire Bestuursorganisatie; Hand- en Leerbóek der Bestuurswetenschappen, Deel 15, N. Sampson nv Alphen aan den Rijn, 1970, pp. 41 et seq.

4 ALBRIGHT, A.D. University Management in Belgium, Institut Administration - Universitè, Brussels, 1970, p. 49.

5 FULLER, B.A. Framework for Academic Planning, J. Higher Educ. XLVII(1): 72, 1976. 